\title{
SEM, EDX, Infrared and Raman spectroscopic characterization of the silicate mineral yuksporite
}

\author{
Ray L. Frost ${ }^{\mathrm{a}, *}$, Andrés López ${ }^{\mathrm{a}}$, Ricardo Scholz ${ }^{\mathrm{b}}$, Frederick L. Theiss ${ }^{\mathrm{a}}$, Antônio Wilson Romano ${ }^{\mathrm{c}}$

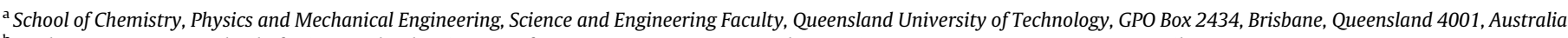 \\ ${ }^{\mathrm{b}}$ Geology Department, School of Mines, Federal University of Ouro Preto, Campus Morro do Cruzeiro, Ouro Preto, MG 35,400-00, Brazil \\ ${ }^{\mathrm{C}}$ Geology Department, Federal University of Minas Gerais, Belo Horizonte, MG 31,270-901, Brazil
}

\section{H I G H L I G H T S}

- The mineral yuksporite has been analyzed.

- Scanning electron microscopy shows a single pure phase with cleavage fragment up to $1.0 \mathrm{~mm}$.

- Chemical analysis gave $\mathrm{Si}, \mathrm{Al}, \mathrm{K}, \mathrm{Na}$ and $\mathrm{Ti}$ as the as major elements with small amounts of Mn, Ca, Fe and REE.

- The mineral was characterized by vibrational spectroscopy.
G R A P H I C A L A B S T R A C T

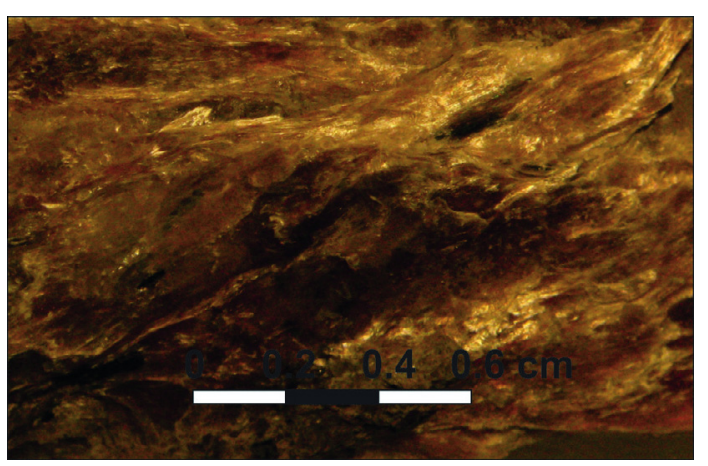

\begin{abstract}
A B S T R A C T
The mineral yuksporite $(\mathrm{K}, \mathrm{Ba}) \mathrm{NaCa}_{2}(\mathrm{Si}, \mathrm{Ti})_{4} \mathrm{O}_{11}(\mathrm{~F}, \mathrm{OH}) \cdot \mathrm{H}_{2} \mathrm{O}$ has been studied using the combination of SEM with EDX and vibrational spectroscopic techniques of Raman and infrared spectroscopy. Scanning electron microscopy shows a single pure phase with cleavage fragment up to $1.0 \mathrm{~mm}$. Chemical analysis gave $\mathrm{Si}, \mathrm{Al}, \mathrm{K}, \mathrm{Na}$ and Ti as the as major elements with small amounts of $\mathrm{Mn}, \mathrm{Ca}$, Fe and REE. Raman bands are observed at $808,871,930,954,980$ and $1087 \mathrm{~cm}^{-1}$ and are typical bands for a natural zeolite. Intense Raman bands are observed at 514, 643 and $668 \mathrm{~cm}^{-1}$. A very sharp band is observed at $3668 \mathrm{~cm}^{-1}$ and is attributed to the $\mathrm{OH}$ stretching vibration of $\mathrm{OH}$ units associated with $\mathrm{Si}$ and Ti. Raman bands resolved at $3298,3460,3562$ and $3628 \mathrm{~cm}^{-1}$ are assigned to water stretching vibrations.
\end{abstract}

(ㄷ) 2014 Elsevier B.V. All rights reserved.

\section{Keywords:}

Yuksporite

Silicate

SEM

EDX

Raman spectroscopy

Infrared spectroscopy

\section{Introduction}

Yuksporite is a rare silicate mineral with general formula given as $(\mathrm{K}, \mathrm{Ba}) \mathrm{NaCa}_{2}(\mathrm{Si}, \mathrm{Ti})_{4} \mathrm{O}_{11}(\mathrm{~F}, \mathrm{OH}) \cdot \mathrm{H}_{2} \mathrm{O}$. The mineral is structurally related to the umbite group of minerals. Umbite has the formula $\mathrm{K} 2(\mathrm{Zr}, \mathrm{Ti}) \mathrm{Si}_{3} \mathrm{O}_{9} \cdot \mathrm{H}_{2} \mathrm{O}$ [1]. Yuksporite was first described from the

\footnotetext{
* Corresponding author. Tel.: +61 73138 2407; fax: +61 731381804 . E-mail address: r.frost@qut.edu.au (R.L. Frost).
}

Hackman Valley, Yukspor Mt, Kola Peninsula, Russia. Alkaline pegmatites are an important source of rare metals such as $\mathrm{Nb}, \mathrm{Zr}$, Rare Earth Elements (REE), Platinum Group Elements (PGE), U as well as other industrial minerals [2,3]. Despite the economic importance, such rocks are of scientific interest only due to the complex mineralogy [4-7].

Over a long period of time, the actual structure of yuksporite was ill determined. The mineral was shown originally to be a triclinic system, space group P1/ and with unit cell parameters determined as: $a=5.49 \AA, b=7.11 \AA, c=14.5 \AA, \alpha=101^{\circ}, \beta=96^{\circ}$, 
$\gamma=90^{\circ}[8]$. Recent studies have refined the structure of yuksporite [9]. Krivovichev et al. showed the mineral to be monoclinic. Krivovichev et al. showed the structure of yuksporite to be based upon titanosilicate nanorods [9]. Silicate tetrahedra form double xonotlite-like chains $1 \times\left[\mathrm{Si}_{6} \mathrm{O}_{17}\right]$ oriented parallel to (001). Two $1 \times\left[\mathrm{Si}_{6} \mathrm{O}_{17}\right]$ chains are linked into a rod via $\mathrm{TiO}_{6}$ octahedra and $\mathrm{Si}_{2} \mathrm{O}_{7}$ double tetrahedra. These authors [9] reported that the $(\mathrm{Ti}, \mathrm{Nb})_{4}(\mathrm{O}, \mathrm{OH})_{4}\left[\mathrm{Si}_{6} \mathrm{O}_{17}\right]_{2}\left[\mathrm{Si}_{2} \mathrm{O}_{7}\right]_{3}$ nanorods are porous. The interior of the titanosilicate nanorods is occupied by $\mathrm{Sr}, \mathrm{Ba}, \mathrm{K}$, and Na cations and $\mathrm{H}_{2} \mathrm{O}$ molecules [9]. The nanorods are separated by walls of Ca coordination polyhedra that are parallel to (010) and link the rods into a three-dimensional structure [9]. The lomonosovite is product of low-temperature hydrothermal activity, occurring in syenite pegmatites [8], and occurs in association with a complex paragenesis $[8,10-12]$.

Yuksporite used in this research was first described in the Hackman Valley, Yukspor Mt, Kola Peninsula, Russia. The Kola Peninsula is the northeastern segment of the Precambrian Baltic Shield, and is characterized by complicated block structures, which were reactivated during several tectono-magmatic episodes. During the Devonian, numerous ultramafic, alkaline and carbonatitic intrusions were emplaced over an area of more than $100,000 \mathrm{~km}^{2}$ which extends from eastern Finland to the eastern Kola Peninsula, and comprise the Kola Alkaline Province (KAP). These various ultramafic and alkaline silicate rocks found in Kovdor are considered to have been formed from several batches of a carbonated olivine melanephelinite parental magma by a mechanism involving fractional crystallization, magma mixing and/or contamination [13].

The Khibiny massif was emplaced during the Devonian (Kramm and Sindern 2004) [14] simultaneously with the subsidence of the NE-SW trending Khibiny-Kontozero-Graben and is the largest agpaitic, nepheline syenite body in the Kola Alkaline Province. In general, Khibiny consists of a variety of nepheline syenites (khibinite, rischorrite, lujavrite and foyaite), foidalites (ijolite and urtite) and minor alkali syenite plus a small carbonatite stock [15].

The aim of this paper is to report the vibrational spectra of yuksporite, and to relate the spectra to this molecular and the crystal structure. The paper follows the systematic research of the large group of oxyanion containing minerals, and especially their molecular structure using IR and Raman spectroscopy.

\section{Experimental}

\section{Samples description and preparation}

The yuksporite sample studied in this work forms part of the collection of the Geology Department of the Federal University of Ouro Preto, Minas Gerais, Brazil, with sample code SAB-087. The sample is from the type locality for the mineral, Yuksporite was first described in the Hackman Valley, Yukspor Mt, Kola Peninsula, Russia.

The yuksporite sample studied occurs as acicular aggregate. The sample was gently crushed and prepared with support of a stereomicroscope Leica MZ4. Scanning electron microscopy (SEM) in the EDS mode was applied to support the mineral characterization.

\section{Scanning electron microscopy (SEM)}

Experiments and analyses involving electron microscopy were performed in the Center of Microscopy of the Universidade Federal de Minas Gerais, Belo Horizonte, Minas Gerais, Brazil (http:// www.microscopia.ufmg.br).

Yuksporite crystal aggregate was coated with a $5 \mathrm{~nm}$ layer of evaporated Au. Secondary Electron and Backscattering Electron images were obtained using a JEOL JSM-6360LV equipment. Qualitative and semi-quantitative chemical analysis in the EDS mode were performed with a ThermoNORAN spectrometer model Quest and was applied to support the mineral characterization.

\section{Raman microprobe spectroscopy}

Crystals of yuksporite were placed on a polished metal surface on the stage of an Olympus BHSM microscope, which is equipped with $10 \times, 20 \times$, and $50 \times$ objectives. The microscope is part of a Renishaw 1000 Raman microscope system, which also includes a monochromator, a filter system and a CCD detector (1024 pixels). The Raman spectra were excited by a Spectra-Physics model 127 He-Ne laser producing highly polarized light at $633 \mathrm{~nm}$ and collected at a nominal resolution of $2 \mathrm{~cm}^{-1}$ and a precision of $\pm 1 \mathrm{~cm}^{-1}$ in the range between 200 and $4000 \mathrm{~cm}^{-1}$. Repeated acquisitions on the crystals using the highest magnification $(50 \times)$ were accumulated to improve the signal to noise ratio of the spectra. Raman Spectra were calibrated using the $520.5 \mathrm{~cm}^{-1}$ line of a silicon wafer. The Raman spectrum of at least 10 crystals was collected to ensure the consistency of the spectra.

\section{Infrared spectroscopy}

Infrared spectra were obtained using a Nicolet Nexus 870 FTIR spectrometer with a smart endurance single bounce diamond ATR cell. Spectra over the $4000-525 \mathrm{~cm}^{-1}$ range were obtained by the co-addition of 128 scans with a resolution of $4 \mathrm{~cm}^{-1}$ and a mirror velocity of $0.6329 \mathrm{~cm} * \mathrm{~s}^{-1}$. Spectra were co-added to improve the signal to noise ratio. The infrared spectra are given in the supplementary information.

Spectral manipulation such as baseline correction/adjustment and smoothing were performed using the Spectracalc software package GRAMS (Galactic Industries Corporation, NH, USA). Band component analysis was undertaken using the Jandel 'Peakfit' software package that enabled the type of fitting function to be selected and allows specific parameters to be fixed or varied accordingly. Band fitting was done using a Lorentzian-Gaussian cross-product function with the minimum number of component bands used for the fitting process. The Gaussian-Lorentzian ratio was maintained at values greater than 0.7 and fitting was undertaken until reproducible results were obtained with squared correlations of $r^{2}$ greater than 0.995 .

\section{Results and discussion}

\section{Chemical characterization}

The SEM image of yuksporite sample studied in this work is shown in Fig. 1. The sample corresponds to a cleavage fragment

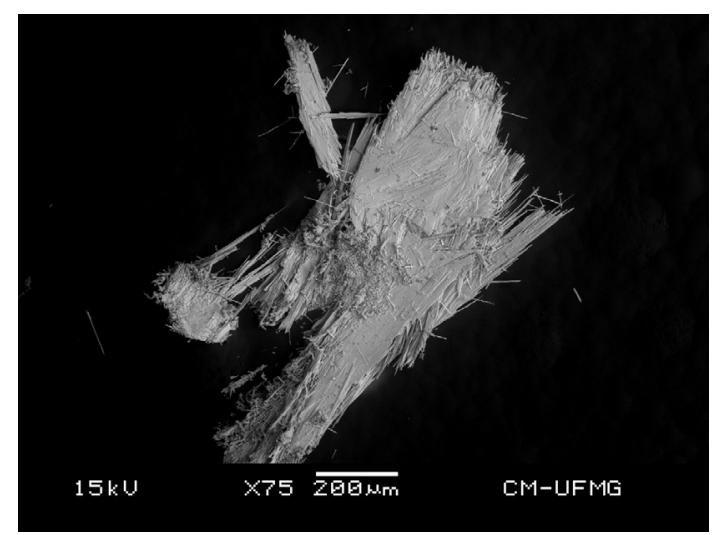

Fig. 1. Backscattered electron image (BSI) of a yuksporite single crystal up to 1.0 $\mathrm{mm}$ in length. 


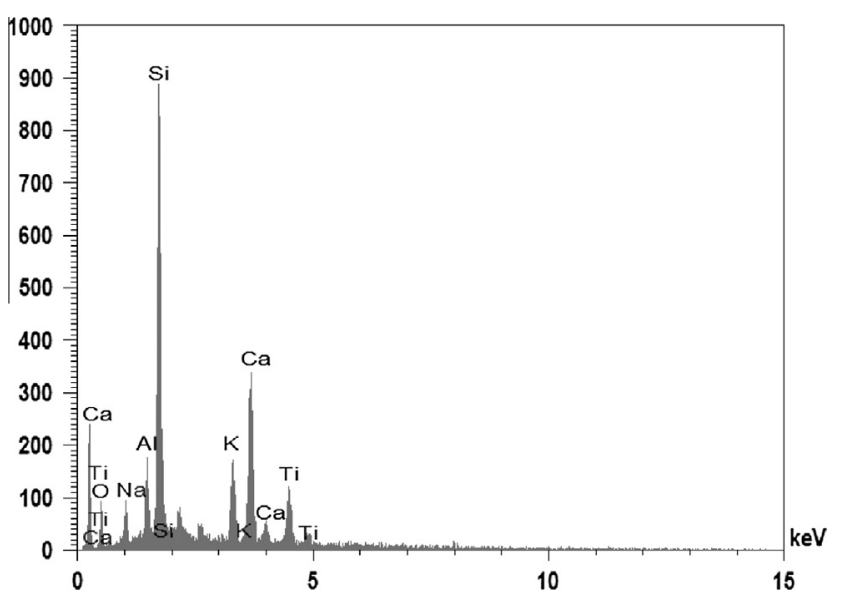

Fig. 2. EDX analysis of yuksporite.

up to $1.0 \mathrm{~mm}$. The SEM image shows a homogeneous mineral with no impurities. Qualitative chemical analysis gave $\mathrm{Si}, \mathrm{Al}, \mathrm{K}, \mathrm{Na}$ and $\mathrm{Ti}$ as the as major elements. Small amounts of Mn, Ca, Fe and REE were also observed (Fig. 2).

\section{Vibrational spectroscopy of yuksporite}

The Raman spectrum of yuksporite over the $100-4000 \mathrm{~cm}^{-1}$ spectral range is shown in Fig. 3a. This figure shows the position and relative intensity of the Raman bands. It is noted there are large parts of the spectrum where little or no intensity is observed. The Raman spectrum is therefore subdivided into sections based upon the types of vibration being studied. It is noted that there is

a

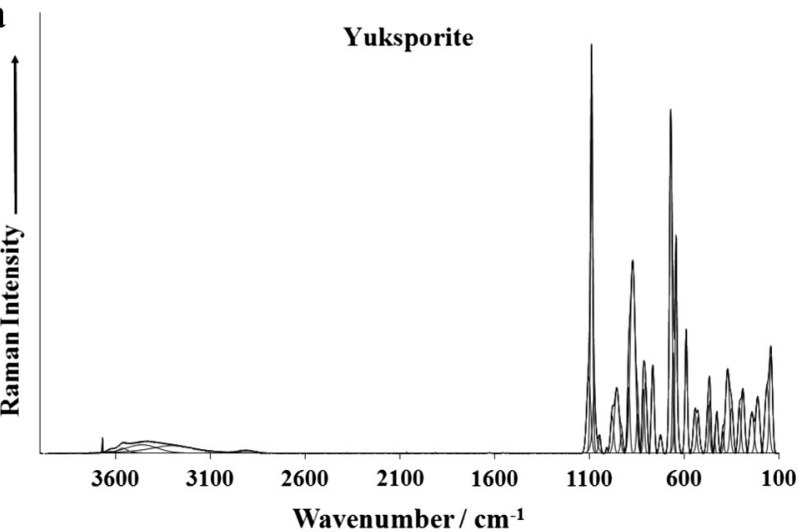

b

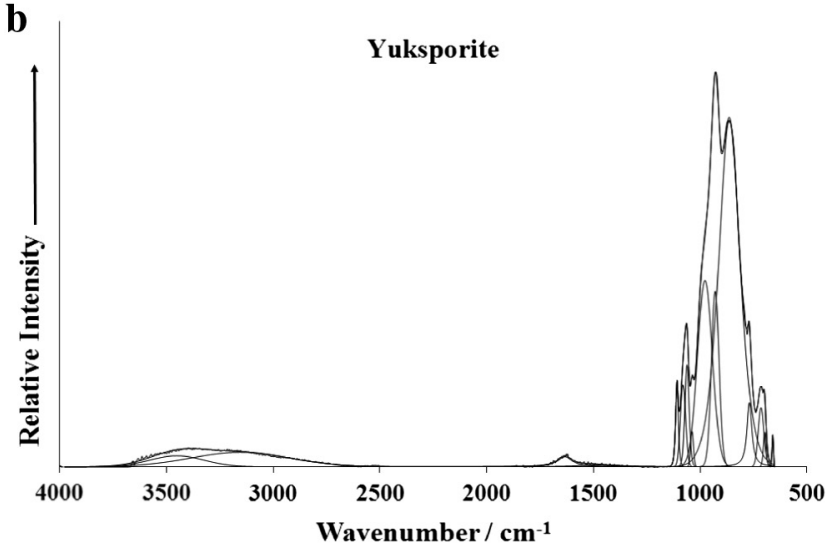

Fig. 3. (a) Raman spectrum of yuksporite (upper spectrum) and (b) infrared spectrum of yuksporite (lower spectrum).
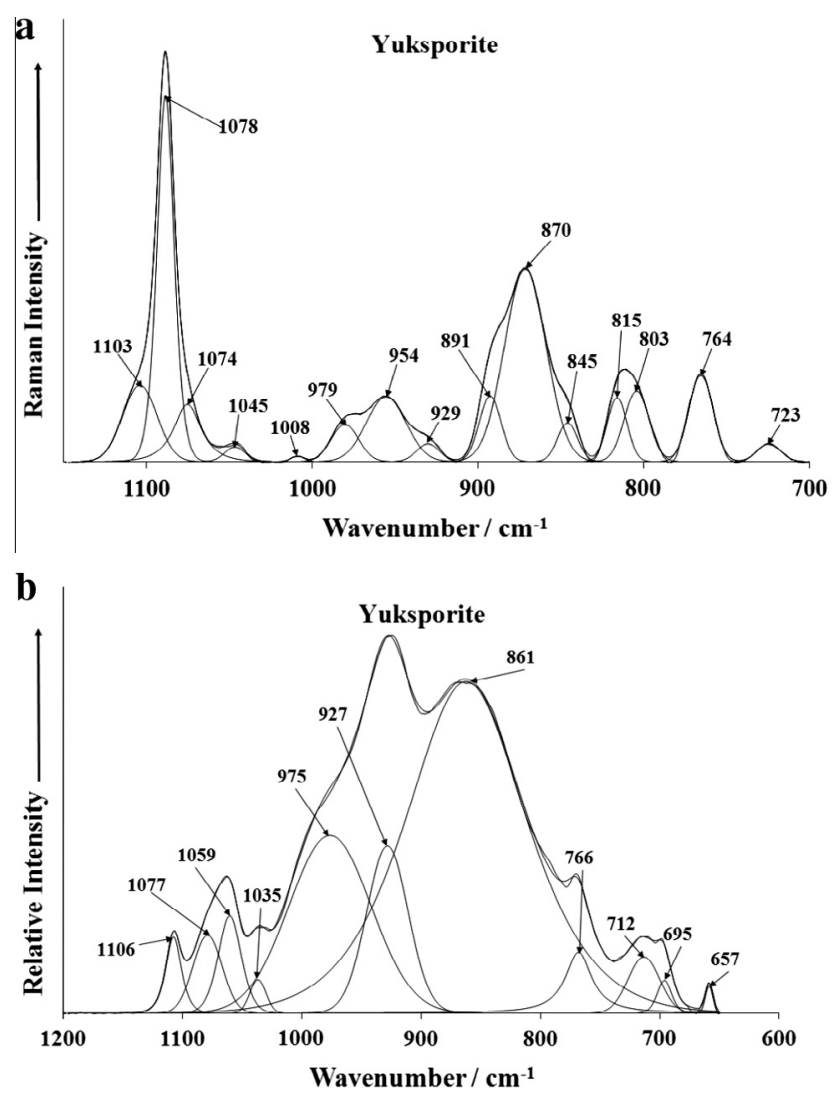

Fig. 4. (a) Raman spectrum of yuksporite (upper spectrum) in the $700-1200 \mathrm{~cm}^{-1}$ spectral range and (b) infrared spectrum of yuksporite (lower spectrum) in the 600$1200 \mathrm{~cm}^{-1}$ spectral range.

little intensity in the hydroxyl stretching region (2500$3800 \mathrm{~cm}^{-1}$ spectral range). The infrared spectrum of yuksporite over the $500-4000 \mathrm{~cm}^{-1}$ spectral range is displayed in Fig. $3 \mathrm{~b}$. This figure shows the position and relative intensities of the infrared bands. There is minimal intensity observed beyond $1500 \mathrm{~cm}^{-1}$. The infrared spectrum is also subdivided into sections based upon the type of vibration being analysed.

The Raman spectrum of yuksporite over the $800-1200 \mathrm{~cm}^{-1}$ spectral range is reported in Fig. 4a. Raman bands are observed at $808,871,930,954,980$ and $1087 \mathrm{~cm}^{-1}$. Raman bands observed are assigned to the $\mathrm{SiO}$ and $\mathrm{TiO}$ stretching vibrations. The position of these bands is typical of natural zeolites. Dowty calculated the band positions for the different ideal silicate units. Dowty showed that the $-\mathrm{SiO}_{3}$ units had a unique band position of $1025 \mathrm{~cm}^{-1}$ [16] (see Figs. 2 and 4 of this reference). Dowty calculated the Raman spectrum for these type of silicate networks and predicted two bands at around 1040 and $1070 \mathrm{~cm}^{-1}$ with an additional band at around $600 \mathrm{~cm}^{-1}$. We observe Raman bands at 1087 and $1110 \mathrm{~cm}^{-1}$ which is in close agreement with the predicted results of Dowty.

The infrared spectrum of yuksporite over the $600-1200 \mathrm{~cm}^{-1}$ spectral range is shown in Fig. $4 \mathrm{~b}$. The infrared spectrum is quite broad and bands may be resolved into component bands. Strong infrared bands are found at 861,927 and $975 \mathrm{~cm}^{-1}$. A group of infrared bands are found at 1035, 1059, 1077 and $1106 \mathrm{~cm}^{-1}$. These bands are the equivalent of the Raman band at $1087 \mathrm{~cm}^{-1}$ and are assigned to the stretching vibrations of the SiO units. Infrared bands are also found at $657,695,712$ and $766 \mathrm{~cm}^{-1}$. These latter three bands are thought to be due to hydroxyl deformations and water librational modes. 

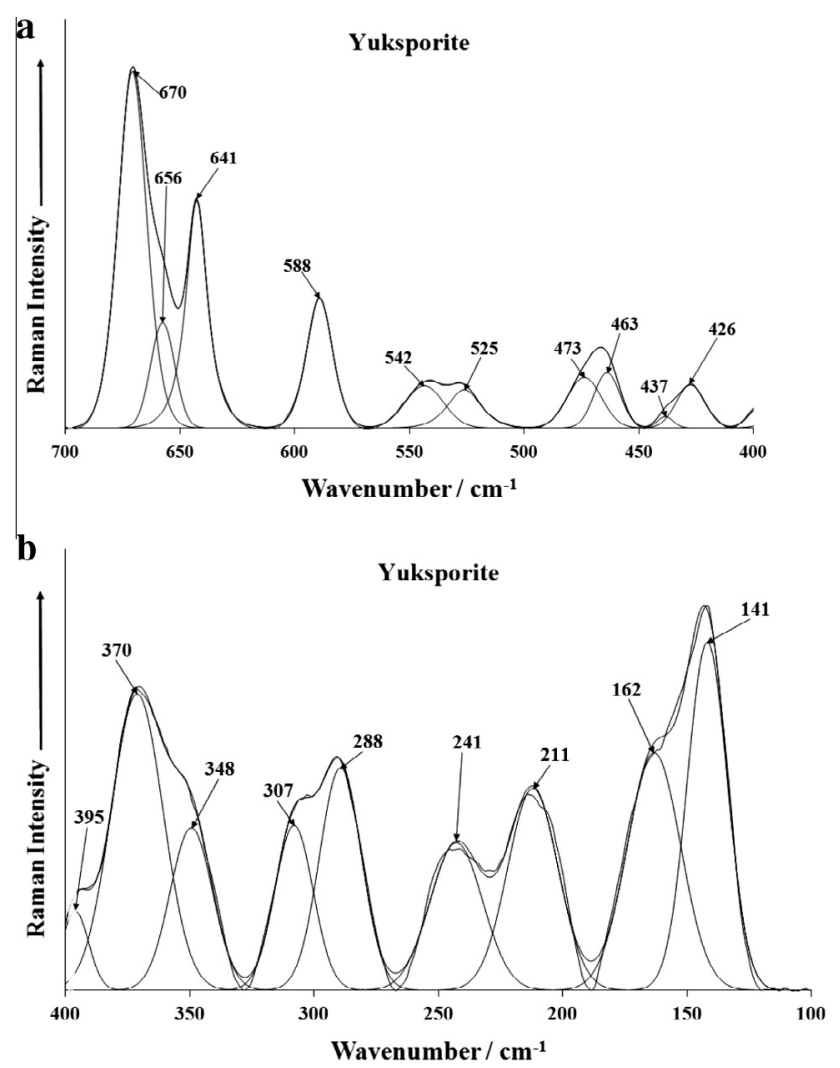

Fig. 5. (a) Raman spectrum of yuksporite (upper spectrum) in the $300-800 \mathrm{~cm}^{-1}$ spectral range and (b) Raman spectrum of yuksporite (lower spectrum) in the 100 $300 \mathrm{~cm}^{-1}$ spectral range.

The Raman spectrum of yuksporite over the $300-800 \mathrm{~cm}^{-1}$ spectral range and over the $100-300 \mathrm{~cm}^{-1}$ spectral range is shown in Fig. 5. Intense Raman bands are observed at 514, 643 and $668 \mathrm{~cm}^{-1}$. Bands of lesser intensity are found at 349, 371, 396, $428,461,476,533,588$ and $765 \mathrm{~cm}^{-1}$. Some of these bands may be ascribed to TiO vibrational modes. Dowty calculated the band position of these bending modes for different siloxane units [16]. Dowty demonstrated the band position of the bending modes for $\mathrm{SiO}_{3}$ units at around $650 \mathrm{~cm}^{-1}$. This calculated value is in harmony with the higher wavenumber bands observed at 643 and $668 \mathrm{~cm}^{-1}$. Raman bands in the $300-400 \mathrm{~cm}^{-1}$ spectral region may be attributed to metal-oxygen vibrations. Raman bands are found at 118 , $138,157,208,240$ and $284 \mathrm{~cm}^{-1}$ (Fig. 5b). These bands are simply described as lattice vibrations.

The formula of yuksporite is $(\mathrm{K}, \mathrm{Ba}) \mathrm{NaCa}_{2}(\mathrm{Si}, \mathrm{Ti})_{4} \mathrm{O}_{11}(\mathrm{~F}, \mathrm{OH}) \cdot \mathrm{H}_{2} \mathrm{O}$. As such it would be expected that bands which could be attributed to water or $\mathrm{OH}$ stretching vibrations. The Raman spectrum of yuksporite over the $2800-3800 \mathrm{~cm}^{-1}$ spectral range is shown in Fig. 6a. A very sharp band is observed at $3668 \mathrm{~cm}^{-1}$ and is attributed to the $\mathrm{OH}$ stretching vibration of $\mathrm{OH}$ units associated with $\mathrm{Si}$ and $\mathrm{Ti}\left((\mathrm{K}, \mathrm{Ba}) \mathrm{NaCa}_{2}(\mathrm{Si}, \mathrm{Ti})_{4} \mathrm{O}_{11}(\mathrm{~F}, \mathrm{OH}) \cdot \mathrm{H}_{2} \mathrm{O}\right)$. A broad spectral profile over the $2800-3650 \mathrm{~cm}^{-1}$ spectral range is observed and bands are resolved at $3298,3460,3562$ and $3628 \mathrm{~cm}^{-1}$. These bands are assigned to water stretching vibrations.

In contrast, the infrared spectrum of yuksporite over the 2600$3800 \mathrm{~cm}^{-1}$ spectral range is reported in Fig. $6 \mathrm{~b}$. The spectrum suffers from a lack of signal, nevertheless, Two bands may be resolved at 3152 and $3448 \mathrm{~cm}^{-1}$. These bands are assigned to water stretching vibrations. This assignment is supported by the infrared spectrum in the $1200-1800 \mathrm{~cm}^{-1}$ spectral range (Fig. 7) where a band observed at $1631 \mathrm{~cm}^{-1}$ is assigned to water bending vibrations.
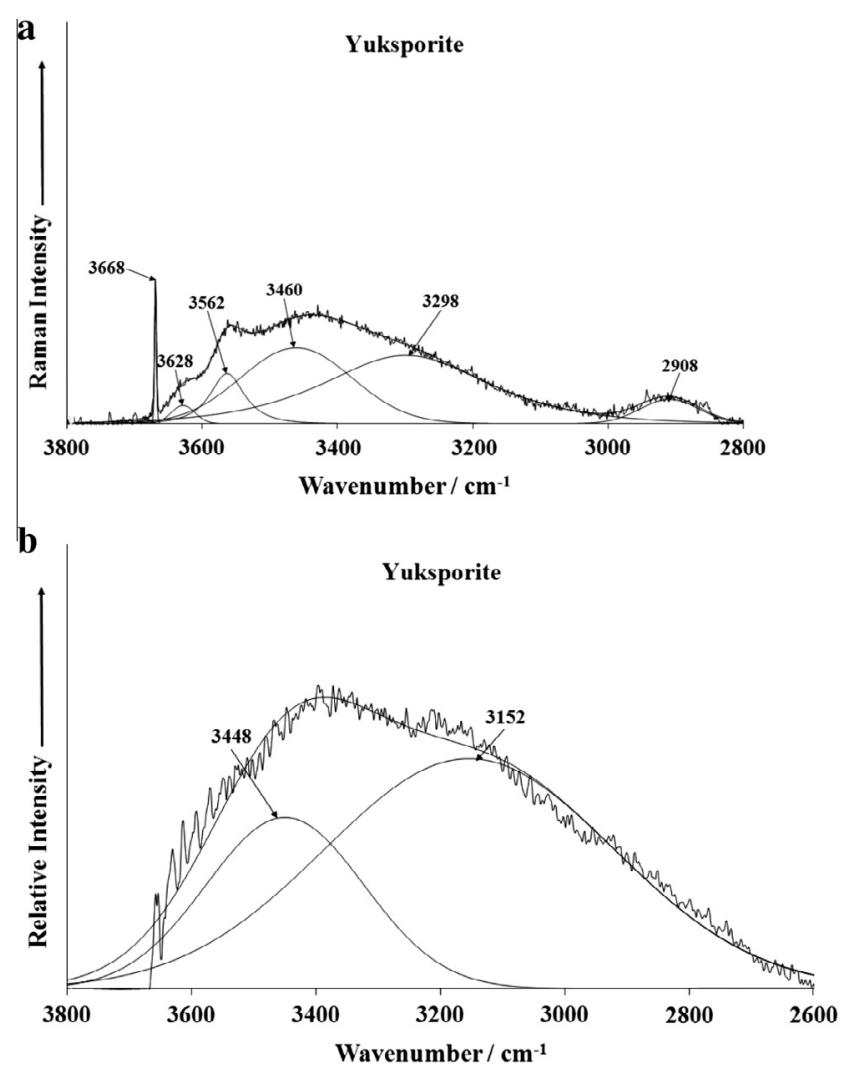

Fig. 6. (a) Raman spectrum of yuksporite (upper spectrum) in the $2800-3800 \mathrm{~cm}^{-1}$ spectral range and (b) infrared spectrum of yuksporite (lower spectrum) in the $2600-3800 \mathrm{~cm}^{-1}$ spectral range.

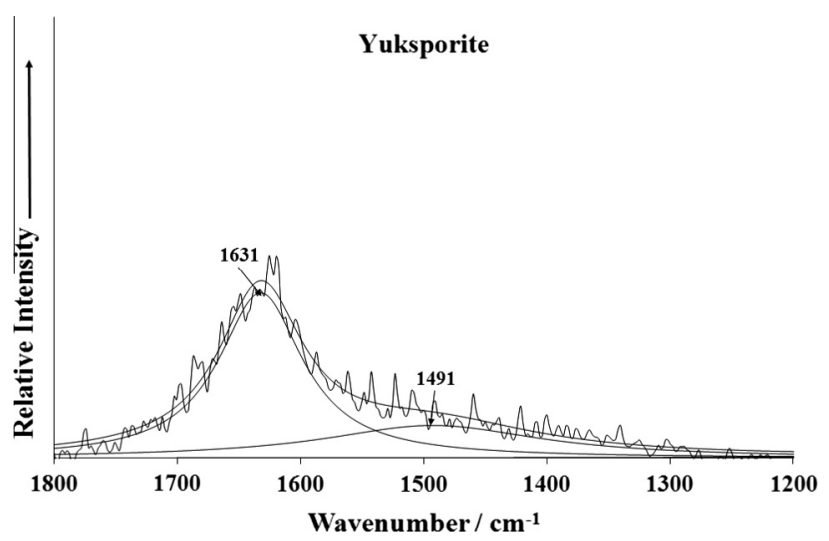

Fig. 7. Infrared spectrum of yuksporite in the $1300-1800 \mathrm{~cm}^{-1}$ spectral range.

\section{Conclusions}

The mineral yuksporite, a rare silicate mineral of accepted formula $(\mathrm{K}, \mathrm{Ba}) \mathrm{NaCa}_{2}(\mathrm{Si}, \mathrm{Ti})_{4} \mathrm{O}_{11}(\mathrm{~F}, \mathrm{OH}) \cdot \mathrm{H}_{2} \mathrm{O}$ was analyzed by scanning electron microscopy which shows a pure single phase with fragments to $1 \mathrm{~mm}$ in length. Chemical analysis using EDX, gave $\mathrm{Si}$, $\mathrm{Al}, \mathrm{K}, \mathrm{Na}$ and $\mathrm{Ti}$ as the as major elements with small amounts of $\mathrm{Mn}, \mathrm{Ca}, \mathrm{Fe}$ and REE.

Raman bands observed at 808, 871, 930, 954, 980 and $1087 \mathrm{~cm}^{-1}$ are typical bands for a natural zeolite. Intense Raman bands are observed at 514, 643 and $668 \mathrm{~cm}^{-1}$. A very sharp band is observed at $3668 \mathrm{~cm}^{-1}$ and is attributed to the $\mathrm{OH}$ stretching vibration of $\mathrm{OH}$ units associated with $\mathrm{Si}$ and Ti. Raman bands resolved at 3298, 3460, 3562 and $3628 \mathrm{~cm}^{-1}$ are assigned to water 
stretching vibrations. Aspects of the structure of yuksporite have been enhanced by vibrational spectroscopy.

\section{Acknowledgments}

The financial and infra-structure support of the Discipline of Nanotechnology and Molecular Science, Science and Engineering Faculty of the Queensland University of Technology, is gratefully acknowledged. The Australian Research Council (ARC) is thanked for funding the instrumentation. The authors would like to acknowledge the Center of Microscopy at the Universidade Federal de Minas Gerais (http://www.microscopia.ufmg.br) for providing the equipment and technical support for experiments involving electron microscopy. R. Scholz thanks to CNPq - Conselho Nacional de Desenvolvimento Científico e Tecnológico (grant No. 306287/ 2012-9). A. Granja offer thanks to FAPEMIG - Fundação de Amparo à Pesquisa do Estado de Minas Gerais.

\section{References}

[1] A.P. Khomyakov, A.A. Voronkov, Y.S. Kobyashev, L.I. Polezhaeva, Zapiski Vses, Mineralog. Obshch 112 (1983) 461-469 (in Russian).

[2] A.A. Arzamastsev, F. Bea, L.V. Arzamastseva, P. Montero, Russian J. Earth Sci. 4 (2002) 187-209.
[3] D. Schissel, A.A. Tsvetkov, F.P. Mitrofanov, A.U. Korchagin, Econ. Geol. 97 (2002) 1657-1677.

[4] A.E. Fersman, Am. Min. 11 (1926) 289-299.

[5] E.I. Semenov, Tr. Inst. Mineralog., Geokhim. i Kristallokhim. Redkikh Elementov (1960) 20-23.

[6] I.P. Tikhonenkov, M.V. Kukharchik, Y.A. Pyatenko, Doklady Akademii Nauk SSSR 134 (1960) 920-923.

[7] E.V. Vlasova, L.V. Kozyreva, Mater. Nauchn. Konf. Mosk. Otd. Vses. Mineral. Ova., 1st (1976) 29-31.

[8] V.I. Gerasimovsky, Doklady Akad. Nauk S. S. S. R. 70 (1950) 83-86.

[9] S.V. Krivovichev, V.N. Yakovenchuk, T. Armbruster, N. Doebelin, P. Pattison, H.P. Weber, W. Depmeier, Am. Min. 89 (2004) 1561-1565.

[10] A.P. Khomyakov, G.N. Nechelyustov, R.K. Rastsvetaeva, K.A. Rozenberg, Zapiski Rossiiskogo Mineralogicheskogo Obshchestva 137 (2008) 43-52.

[11] N.V. Chukanov, I.V. Pekov, L.V. Olysych, W. Massac, O.V. Yakubovich, A.E Zadov, R.K. Rastsvetaeva, M.F. Vigasina, Kyanoxalite, a new cancrinite-group mineral species with extraframework oxalate anion from the lovozero alkaline pluton, Kola Peninsula, Geology of Ore Deposits, 2010, Pleiades Publishing Ltd, 52 (2010) 778-790.

[12] I.V. Pekov, N.V. Zubkova, Y.E. Filinchuk, N.V. Chukanovc, A.E. Zadov, D.Y. Pushcharovsky, E.R. Gobechiya, Geology of Ore Deposits, vol. 52, Pleiades Publishing, Ltd, 2010, 2010, pp. 767-777.

[13] M.J. Lee, J.I. Lee, S.D. Hur, Y. Kim, J. Moutte, E. Balaganskaya, Lithos 91 (2006) $250-261$.

[14] U. Kramm, S. Sindern, Timing of Kola ultrabasic, carbonatite and phoscoritecarbonatite magmatism, Mineralogical Society Book Series, 2004.

[15] V.N. Yakovenchuk, G.J. Ivanyuk, Y.A. Pahomovsky, Y.P. Men'shikov, Minerals of the Khibiny Massif. Zemlya, Moscow, 1999 (in Russian).

[16] E. Dowty, Phys. Chem. Min. 14 (1987) 80-93. 